\title{
Awareness Levels of Child Neglect and Abuse in Nursing Students
}

\author{
DOI: 10.26466/opus.885123
}

\author{
Suzan Tek ${ }^{*}$ - Gizem Karakaş** \\ *Asisst. Prof. Dr., Yozgat Bozok University , Yozgat/Turkey \\ E-Mail: suzan.tek@bozok.edu.tr \\ ORCID: $\underline{0000-0002-4969-9348}$ \\ **Phd.. Nursing, Yakın Doğu University, Lefkoşa/KKTC \\ E-Mail: gizemkarakas1993@hotmail.com \\ ORCID: $\underline{0000-0003-2490-1519}$
}

\begin{abstract}
The aim of this study was to determine the awareness level of the students in the Yakın Doğu-Near East University Nursing Faculty about child neglect and abuse. The population of this descriptive study was composed of 520 students. In order to collect the data, Questionnaire for Socio-demographic Characteristics to determine sociodemographic characteristics of the students and The Diagnosis Scale of the Risks and Symptoms of Child Abuse and Neglect (DSRSCAN) were used, in December 2018 - June 2019. Obtained data were analyzed by their percentage, distributions and average. Kruskal Wallis $H$ Test and Mann Witney-U Test were also used. According to the results of the research, it was found that there was a significant difference between the students' gender, class, knowledge child neglect and abuse, the case of child neglect and abuse case or suspicion and the level of awareness about child neglect and abuse. There was no statistically significant for age. While the highest mean score of the students was obtained in "signs of neglect on child" subscale, the lowest mean score was obtained in 'characteristics of children prone to abuse and neglect" subscale. Total scale mean score was 3.45+0.45. It was determined that the students' level of awareness about child neglect and abuse was not sufficient. More emphasis on child neglect and abuse in the nursing education curriculum may be important in raising the awareness level of the students.
\end{abstract}

Key Words: Child Abuse, Child Neglect, Nurse, Nursing Students. 


\section{Hemşirelik Öğrencilerinin Çocuk İhmali ve İstismarı Konusundaki Farkındalık Düzeyleri}

Öz

Bu araştırma Yakın Doğu Üniversitesi Hemşirelik Fakültesinde öğrenim gören öğrencilerin çocuk ihmali ve istismar konusunda farkındalık düzeylerinin belirlenmesi amacıyla, yapılmıştır. Tanımlayıcı tipte yapılan araştırmanın örneklemi 520 öğrenciden oluşmaktadır. Aralık 2018 - Haziran 2019 tarihleri arasinda toplanan verilerde, öğrencilerin sosyodemografik özelliklerini belirlemeye yönelik Sosyodemografik Özellikler Anket Formu ve Çocuk İstismarı ve İhmali Belirti ve Risklerini Tanılama Ölçeği (Çİ̈BRTÖ) kullanılmıştır. Verilerin analizinde sayı, yüzde dağılımı yapılmış, Kruskall Wallis $H$ Testi ve Mann Witney- U Testi kullanılmıştır. Araştırma sonuçlarına göre öğrencilerin, cinsiyet, sınıf, çocuk ihmali ve istismarı konusunda bilgi alma durumu, çocuk ihmali ve istismarı vakası veya şüphesi ile karşılaşma durumu değişkenleri ile çocuk ihmali ve istismarı konusunda farkındalık düzeyleri arasında anlaml farkllık saptanırken, yaş değişkeni ile istatistiksel olarak anlaml fark olmadığ belirlenmiştir. Öğrencilerin Çİ̈BRTÖ'nde en yüksek puan ortalaması 'ihmal belirtileri' alt boyutunda iken, en düşük puan ortalaması 'ihmal ve istismara yatkın çocuk özellikleri" alt boyut puan ortalamasıdır. Toplam ölçek puan ortalaması $3.45 \pm 0.45$ 'dir. Öğrencilerin çocuk ihmali ve istismarı konusunda farkındalık düzeylerinin yeterli olmadı̆̆ı saptanmıştır. Hemşirelik eğitim müfredatında çocuk ihmali ve istismarı konusuna daha fazla yer verilmesi öğrencilerin bu konuda farkındalı düzeylerinin artırlmasinda önemli olabilir.

Anahtar Kelimeler : Çocuk İhmali, Çocuk İstismarı, Hemşire, Hemşirelik Öğrencileri. 


\section{Introduction}

Child neglect and abuse is one of today's major health issues. Therefore, its importance is gradually increasing both in the world and in Turkey (Krug et al., 2002). According to World Health Organization's data (2016), 36\% of children have been exposed to emotional abuse, $26 \%$ to sexual abuse, $23 \%$ to physical abuse and $16 \%$ to physical abuse (WHO, 2016). It was stated that globally, one million children aged 2-17 years experienced physical, sexual, emotional violence or abuse (Hills et al., 2016). 4.1 million children in the USA were reported to face assault (Guedes, 2016). While no nationwide study on child abuse was conducted in Turkey, there are studies conducted with small sample groups. According to only official data on the number of child victims in Turkey, the number of child victims which was 74.064 in 2014 rose to 83.552 in 2016 (Polat and Reva, 2019). According to the data of Children's Position and Children's Rights in Northern Cyprus (2009), it is stated that $17 \%$ of children cannot always eat regularly, $8.2 \%$ are exposed to physical violence in school life and $7.9 \%$ are frequently exposed to physical abuse on streets (KADEM, 2009).

According to the Child Abuse Report in Turkey (2018), it is remarkable that the subject requires a multidisciplinary study; however, child abuse is not included sufficiently in the curricula of the students studying in health, law, psychology, social services, security majors in this field (Polat and Reva, 2019). In the previous studies, it was concluded that almost half of the nurses were inadequate about the procedure they should follow in case of child neglect and abuse case and they did not have the knowledge, skills or confidence to diagnose the cases (Gölge, Hamzaoğlu and Türk, 2012; Lavigne, 2014; Metinyurt and Sarl, 2016). According to the study by Metinyurt and Sarı (2016), 59.1\% of the healthcare professionals during undergraduate education and 98.2\% after graduation did not receive training about child neglect and abuse. According to the results of similar studies, it was determined that more than half ot the students did not receive enough information about child abuse and neglect during their education (Özbey et all., 2018; GüdekSeferoğlu, Sezici and Yiğit, 2019). 
Child neglect and abuse, which is one of the most important health problems, unfortunately remains up-to-date and requires new studies in the field. No study was found about the awareness levels of nursing students about child neglect and abuse in Turkish Republic of Northern Cyprus (T.R.N.C.). Nursing students are more likely to encounter child neglect and abuse both during their education period and after graduation compared to the other members of the team. Awareness is the key step in diagnosing and preventing child neglect and abuse.

Therefore, it is important to determine the awareness levels of nursing students regarding child neglect and abuse. The aim of this study was to determine the awareness levels of nursing students about child neglect and abuse.

\section{Research Questions}

- What is the awareness level of nursing students in diagnosing the symptoms and risks of child neglect and abuse?

- Is there a difference their awareness levels in the diagnosis of the symptoms and risks of child neglect and abuse of nursing students according to sociodemographic characteristics?

\section{Method}

\section{Type, Location and Time of the Research}

This descriptive study was conducted with 520 students in the Nursing Faculty in Near East University. The data of the study were collected between December 2018 and June 2019.

\section{The Universe and Sampling of the Research}

All of the students formed the universe of the research $(n=532)$. It was planned to reach the entire universe by not choosing the sample. In the study, inclusion criteria are that the student should be able to speak Turkish and the agrees to participate in the study. 12 of the students did not accept the application. In the study sample, 520 students (98\%) who met the study criteria were included. 


\section{Data Collection}

In study, data collection forms were distributed to the students and they filled in the forms themselves. In order to collect the data, Questionnaire for Socio-demographic Characteristics to determine sociodemographic characteristics of the students and The Diagnosis Scale of the Risks and Symptoms of Child Abuse and Neglect (DSRSCAN) were used (Uysal, 1998).

\section{Introductory Information Form}

Questionnaire for Socio-Demographic Characteristics prepared by the researcher by reviewing the literature, is composed of 14 questions about the age, gender, class, and status of receiving information about abuse and neglect.

DSRSCAN was developed by Uysal in 1998 and its reliability and validity study was conducted. The Cronbach's alpha value of the scale was stated as 0.924 by Uysal. On the other hand, the Cronbach's alpha value for this study was found as 0.909 . The scale is a Likert type scale consisting of 67 items and six subscales; physical signs of neglect on child (PSNC), behavioral symptoms of abuse and neglect in child (BSANC), signs of neglect on child (SONC), parental characteristics prone to abuse and neglect (PCPAN), characteristics of children prone to abuse and neglect (CCPAN), and family characteristics in child abuse and neglect (FCCAN). There are five-point response options for each item consisting of "very correct", "quite correct", "not decided", "not quite right", and "not true at all". The items 3, 5, 8, 10, 12, 14, 16, 27, 28, 30, 32, 34, 41, 42, $46,49,52,54,56,59,61$, and 63 of the scale are reversely coded. The mean score of the scale is obtained by summing the responses given to each item and dividing the result into the number of items. While the mean score of the scale approaching to 5 refers to that the questions are correctly answered, mean score away from 3 shows that they answer incorrectly. In this study, the validity-reliability value (Cronbach's Alpha coefficient) was found to be 0.848 . 


\section{Evaluation of the Data}

The data obtained from the study were transferred into SPSS 22 program. The conformity of the data to the normal distribution was tested with the Kolmogorov-Smirnov test. Since there was no normal distribution, the non-parametric test Mann Whitney-U Test and Kruskal Wallis $\mathrm{H}$ Test were used.

\section{Ethical Aspect of the Research}

Institutional permission was obtained on 17.12.2018 from Near East University Nursing Faculty and approval from ethics committee was obtained on 20.12.2018. The purpose and duration of the study and the form were explained to the students and their consents were obtained by stating that participation was voluntary basis.

\section{Limitation}

The study was conducted in an institution, and the results only cover students at the school where the study was conducted. In addition, study data can only be obtained from students. Another limitation of the study is that it does not contain observational findings.

\section{Results}

It was determined that $58.1 \%(\mathrm{n}=302)$ of the students participating in the study were female, $53.7 \%(\mathrm{n}=279)$ were between the ages of $21-23$, and $29.6 \%(n=154)$ were $4^{\text {th }}$-year students. Also, $62.3 \%(n=324)$ of the students received information about child neglect and abuse in their education life, $74.4 \%$ ( $n=387)$ needed more information, and $69.4 \%$ of the students $(n=361)$ stated that they did not encounter any child neglect and abuse case, $83.1 \%(n=432)$ stated that they would report when they encounter any child neglect and abuse case or suspicion (Table 1). 
Table 1. Socio-Demographic Characteristics and CNA variables

\begin{tabular}{lll}
\hline Variables & $\mathbf{n}$ & \% \\
\hline Gender & 302 & \\
Female & 218 & 58.1 \\
Male & & 41.9 \\
Age & 195 & 37.5 \\
$18-20$ & 279 & 53.7 \\
$21-23$ & 46 & 8.8 \\
24 and over & & \\
Income Level & 128 & 24.6 \\
Income less than expenses & 326 & 62.7 \\
Income equal to expenses & 66 & 12.7 \\
Income more than expenses & & \\
Year & 96 & 18.5 \\
$1^{\text {st }}$ Year & 138 & 26.5 \\
$2^{\text {nd }}$ Year & 132 & 25.4 \\
$3^{\text {rd }}$ Year & 154 & 29.6 \\
$4^{\text {th }}$ Year & & \\
Receiving information about child neglect and abuse in your education life & 324 & 62.3 \\
Yes & 196 & 37.7 \\
No & & \\
Need to know more about child neglect and abuse & 387 & 74.4 \\
Yes & 133 & 25.6 \\
No & & \\
Encountering any child neglect or abuse case or suspicion & 159 & 30.6 \\
I did & 361 & 69.4 \\
I did not & & \\
Reporting in case or suspicion of child neglect and abuse & 432 & 83.1 \\
I do & 88 & 16.9 \\
I do not & &
\end{tabular}

The student's total scale of The Diagnosis Scale of the Risks and Symptoms of Child Abus and Neglect mean score was 3.45+0.45. While the highest mean score of the students was obtained in "signs of neglect on child" subscale $(3.75 \pm 0.58)$, the lowest mean score was obtained in 'characteristics of children prone to abuse and neglect" subscale (2.89 \pm 0.40$)$ (Table 2).

When subscale mean scores of the students were examined based on gender, a significant difference was found in all subscales of DSRSCAN in terms of gender except for 'Characteristics of children prone to abuse and neglect' subscale. DSRSCAN subscale mean score of the female nursing students $(3.50 \pm 0.33)$ was determined to be higher than the score of male students $(3.35 \pm 0.27)$ and the difference between the groups was statistically significant. 
Table 2. DSRSCAN subscale mean score

\begin{tabular}{|c|c|c|c|c|}
\hline & Mean score \pm sd & $\min -\max$ & Item mean score \pm sd & $\min -\max$ \\
\hline Physical signs of neglect on child & $67.54+7.88$ & $(46-89)$ & $3.55 \pm 0.41$ & $(0-5)$ \\
\hline $\begin{array}{l}\text { Behavioral symptoms of abuse an } \\
\text { neglect in child }\end{array}$ & nd52.74 +6.53 & $(33-71)$ & $3.51 \pm 0.43$ & $(0-5)$ \\
\hline Signs of neglect on child & $26.25 \pm 4.12$ & $(13-35)$ & $3.75 \pm 0.58$ & $(0-5)$ \\
\hline $\begin{array}{l}\text { Parental characteristics prone } \\
\text { abuse and neglect }\end{array}$ & to $41.97+4.58$ & $(26-61)$ & $3.22 \pm 0.35$ & $(0-5)$ \\
\hline $\begin{array}{l}\text { Characteristics of children prone } t \\
\text { abuse and neglect }\end{array}$ & to $14.48+2.00$ & $(9-23)$ & $2.89 \pm 0.40$ & $(0-5)$ \\
\hline $\begin{array}{l}\text { Family Characteristics on Chil } \\
\text { Abuse and Neglect }\end{array}$ & ild $27.51 \pm 4.30$ & $(16-40)$ & $3.43 \pm 0.53$ & $(0-5)$ \\
\hline Total Scale Mean Score & $231.6 \pm 21.49$ & $(167-305)$ & $3.45 \pm 0.45$ & $(0-5)$ \\
\hline
\end{tabular}

Table 3. DSRSCAN subscale mean score of the students in some variables

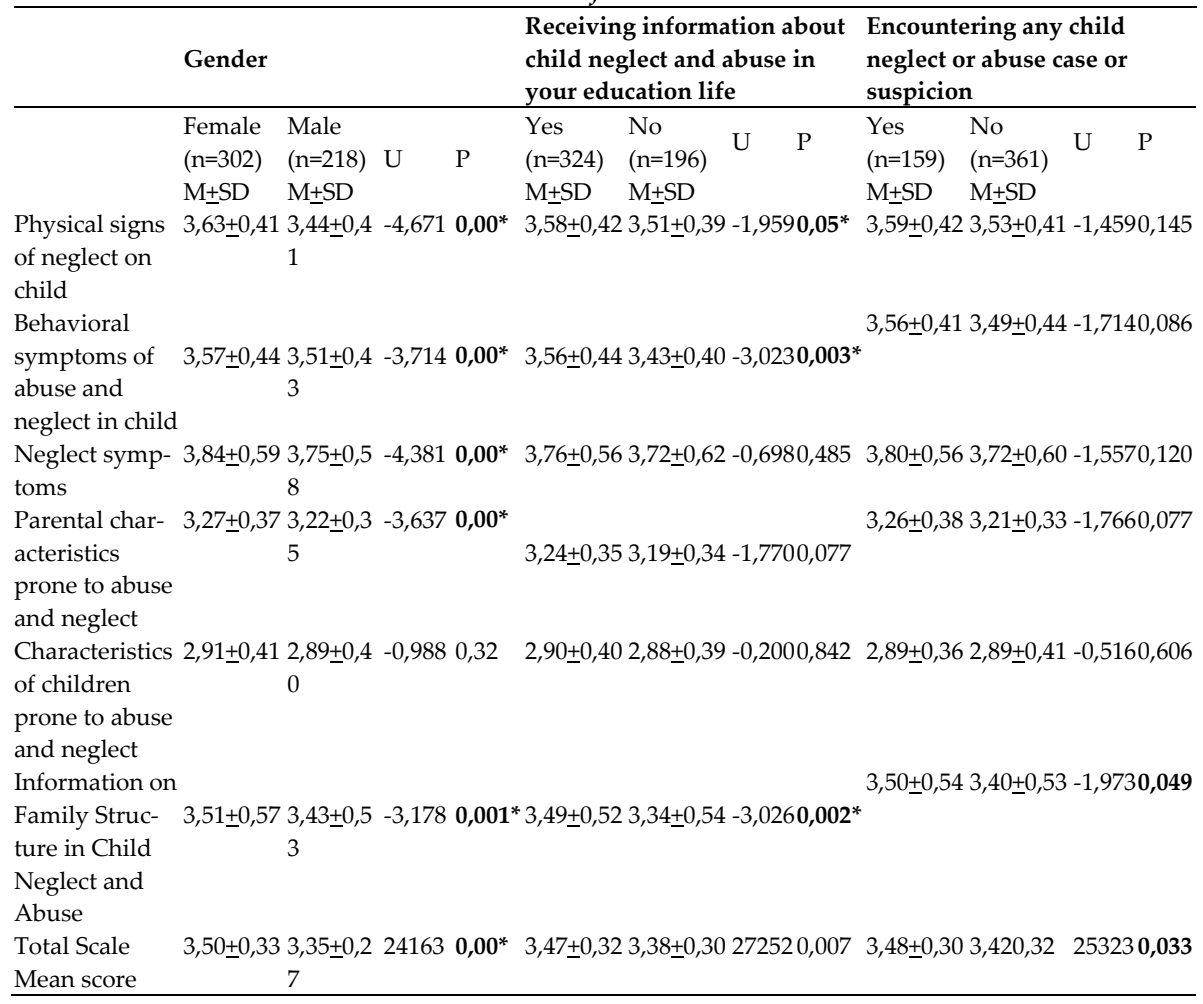

*Mann Witney-U Testi 
Table 4. DSRSCAN subscale mean score of the students age and in terms of year

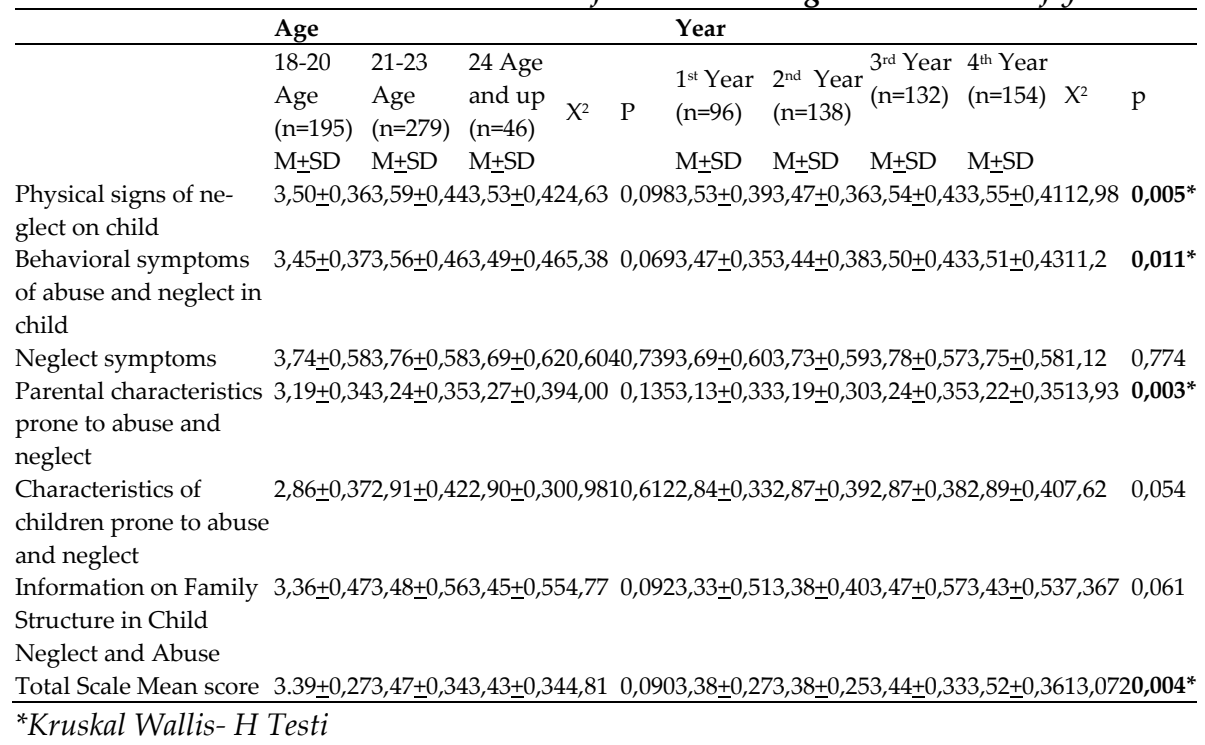

The significant difference was found receive information about child neglect and abuse in your education life (physical signs of neglect on child $(p=0,05, p<0,05)$, behavioral symptoms of abuse and neglect in child' subscale $(\mathrm{p}=0,003, \mathrm{p}<0,05)$ and family structure to neglect and abuse' subscale $(p=0,002, p<0,05)$. DSRSCAN subscale mean score of the nursing students who receive information about child neglect and abuse was determined to be higher than the score of other students. The students who encounter any child neglect or abuse case or suspicion, a significant difference was found in family structure subscales $(\mathrm{p}=0,049$, $\mathrm{p}<0,05)$ and total scale mean score $(\mathrm{p}=0,033, \mathrm{p}<0,05)$ of DSRSCAN (Table $3)$.

While a statistically significant difference was determined in 'physical signs of neglect on child' subscale $(\mathrm{p}=0.005, \mathrm{P}<0.05)$, 'behavioral symptoms of abuse and neglect in child' subscale ( $\mathrm{p}=0.011, \mathrm{p}<0.05)$, and 'Parental characteristics prone to neglect and abuse' subscale $(\mathrm{p}=0.003$, $\mathrm{p}<0.05$ ) of the nursing students, the difference in the other subscales was not statistically significant. DSRSCAN subscale total mean score of $4^{\text {th }}$ year students $(3.52 \pm 0.36)$ was higher than the other years and the difference between the students' year and DSRSCAN subscale mean score was 
significant $(\mathrm{p}=0.004, \mathrm{p}<0.05)$. In the Post-Hoc advanced analysis, this significance was determined to be caused by the difference between the mean scores of $4^{\text {th }}$ and $2^{\text {nd }}$ years in 'physical signs of neglect on child' subscale and 'şit was caused by the difference between the mean scores of the $4^{\text {th }}$ and $1^{\text {st }}$ years in the 'Parental characteristics prone to abuse and neglect' subscale. When subscale mean scores of the students were examined based on age, a significant difference was not found in all subscales of DSRSCAN (Table 4).

\section{Discussion}

In the study, it was determined that although the students' levels of identifying child neglect and abuse were higher than the average (3.45 \pm 0.45$)$, they were not enough. This result was similar to the results of the study on identifying the awareness levels of students and nurses (Metinyurt and Sarı, 2016; Burç and Güdücü Tüfekçi, 2015). In a limited number of studies conducted with nursing students, it was reported that the students had insufficient knowledge and education needs about CNA (Poreddi et al., 2016). It was determined that more than half of the students participating in the study $(62.3 \%)$ received education about child neglect and abuse. In the literature, the status of receiving information about abuse and neglect during nursing education varies. The status of receiving information about abuse and neglect during nursing education was determined as $67.7 \%$ in the study by Seferoğlu et al., (2019), 52.5\% in the study by Burç and Tüfekci (2015) and $13.5 \%$ in the study by Uncu and Oğuzöncül (2013). This difference between the study results may be caused by the education curriculum in nursing schools. On the other hand, the majority of the related studies have been conducted with working nurses. Nurses' status of not remembering their past educational experiences may also be effective. Although the basic structure of the education is determined by nursing framework education program, the absence of a standard in terms of time and content about neglect and abuse during education is one of the main reasons for this difference. The fact that almost $1 / 4$ of the students $(74.4 \%)$ stated that they needed information about this issue supports that this matter is not sufficiently included in the curriculum. The study results show similari- 
ties (Poreddi et al., 2016). On the other hand, when considering that the working years of nurses are in a wide range, conducting the studies on lack of knowledge in this field with students would be a correct research approach.

The scale sub-dimension of the students who received information about child neglect and abuse during their education was higher than those who did not. These sub-dimensions are related to the child's physical, behavioral symptoms and family structure. This result, which is also compatible with the literature (Burç and Güdücü Tüfekçi, 2015), can be interpreted as that students who receive information may be more advantageous in recognizing negligence and abuse.

It was found based on the result of the study that one out of three students (30.6\%) encountered child neglect and abuse case or suspicion and three out of four students $(83.1 \%)$ would report when they encountered child neglect and abuse case or suspicion. Additionally, the mean score of the students who encountered child neglect and abuse case or suspicion was higher than those who did not. In the studies conducted with healthcare professionals, it was determined that while the rate of encountering child neglect and abuse case or suspicion was about $20 \%$, the knowledge about reporting perception was insufficient (Metinyurt and Sarı, 2016; Güdek-Seferoğlu, Sezici and Yiğit, 2019; Başdaş and Bozdağ, 2018). The fact that the rate of encountering child abuse and neglect is incontrovertibly high is an important result in terms of suggesting that neglect and abuse may actually occur at a higher rate. In addition, the high rate of students stating that they would report in the present study may suggest that the students are aware of the importance of the subject. The studies conducted on increasing the reporting rates have focused on mandatory reporting and education programs. According to this limited number of studies, education programs increase the intention of reporting (Victor-Chmil and Foote, 2016; Lee and Chou, 2017; Cho and Kim, 2016).

DSRSCAN total and subscale mean scores of the female students were higher than male students. The study results about the effect of gender of healthcare professionals in child abuse and neglect literature vary (Güdek-Seferoğlu, Sezici and Yiğit, 2019; Burç and Güdücü Tüfekçi, 2015; Uncu and Oğuzöncül, 2013; Başdaş and Bozdağ, 2018; Özçevik, 
Güneş and Ocakçı, 2018). In the literature review by Read et al. (2018), male staff members asked less often than female staff members (Read et al., 2018). Female clinicians were significantly more likely than their male counterparts to record at least one type of abuse or neglect and male staff members were significantly more likely to leave the abuse/neglect section blank (Sampson and Read, 2017).

There was a difference between the awareness of the students included in the study according to their classes. This result is similar to the literature (Güdek-Seferoğlu, Sezici and Yiğit, 2019; Burç and Güdücü Tüfekçi, 2015; Cho and Kim, 2016). This was caused by the fact that courses related to child health are included more in the last year and therefore students encounter with information and practices about children more frequently.

\section{Conclusion}

The knowledge level of nursing student, who play an important role especially in children's health, on child abuse and neglect in their future career should be planned and implemented effectively by the managers of health care centers and hospitals. The study results support nursing curricula need to improve the curricular content related to the assessment and training about child abuse and neglect. Curricular changes may provide nurses with an opportunity to reduce the prevalence of child abuse and neglect. Additionally, the results of the present study could be used to improve policies for awareness risk of child abuse and neglect and to ensure their protection and health promotion as a professional responsibility.

\section{References}

Başdaş, Ö. and Bozdağ, F. (2018). Hemşirelerin çocuk istismarı ve ihmalinin belirti ve risklerini tanılama durumlarının belirlenmesi. Mersin Üniversitesi Saglk Bilimleri Dergisi, 11(3) 267-275.

Burç, A. and Güdücü Tüfekçi, F. (2015). Hemşirelerin çocuk istismarı ve ihmalinin belirti ve risklerini tanılama düzeyleri. Acıbadem Universitesi Saghk Bilimleri Dergisi, 6(3), 144-151. 
Cho, K. and Kim E. (2016). Nursing students' knowledge, attitudes, perceived behavior control and intention to report cases of child abuse. Child Health Nurs Res, 22(2), 145-152

Gölge, Z. B., Hamzaoğlu, N. and Türk, B. (2012). Sağlık çalışanlarının çocuk istismarı ve ihmali konusundaki farkındalık düzeylerinin ölçülmesi. $\begin{array}{llll}\text { Adli Tip Dergisi, } & \text { 26(2), }\end{array}$ https://dx.doi.org/10.5505/adlitip.2012.36349

Guedes, A. (2016). Violence aganist children in Latin America and Caribbean, data and action. Pan American Health Organization / World Health Organization Regional Office for the America. (cited 2020 May 4). Available from: https://www.paho.org/hq/index.php?option=com docmanEview=download Eslug=violence-against-children-in-latin-america-and-the-caribbean-dataand action EItemid $=270 \mathcal{E}$ lang $=e n$

Güdek-Seferoğlu, E., Sezici, E. and Yiğit, D. (2019). Hemşirelik öğrencilerinin çocuk istismarı ve ihmalinin belirti ve risklerini tanılama düzeyleri. OPUS-Uluslararası Toplum Araştırmaları Dergisi , 10(17), 257-276. DOI: 10.26466/opus.511405

Hills, S., Mercy, J., Amobi, A. and Kress, H. (2016). Global prevalence of past-year violence against children: A systematic review and minimum estimates. Pediatrics, 137(3), e20154079.

KADEM. Sos Çocuk köyü Derneği Kuzey Kıbrıs'ta Çocukların Konumu ve Çocuk Hakları Araştırma Raporu. 2009. (cited 2020 May 4). Available from: http://www.soscocukkoyu.org/wpcontent/uploads/2016/12/KADEM$\%$ C3\%87ocuk-Haklar\%C4\%B1- Ara\%C5\%9Ft\%C4\%B1rma-Raporu2009.pdf.11.10.2017a

Krug, E.G., Dahlberg, L.L., Mercy, J.A., Zwi, A.B. and Lozano, R. (Eds.). (2002). World report on violence and health. Geneva: World Health Organization. (cited 2020 May 4). Available from: https://www.who.int/violence injury prevention/violence/world reportlen lintroduction.pdf

Lavigne, J.L. (2014). Pediatric inpatient nurses' knowledge and perceptions of child maltreatment. The University of North Carolina Master Thesis,, North Carolina. (cited 2020 May 4). Available from: https://www.researchgate.net/publication/330824426 Pediatric Inpatient Nurses' Perceptions of Child Maltreatment 
Lee, P. and Chou, F. A. (2017). Training programme for Taiwan nurses to improve child abuse reporting, Journal of Clinical Nursing, 26(15-16), 2297-2306. https://doi.org/10.1111/jocn.13447

Metinyurt, H. A. I. ve Sarı, H. Y. (2016). Sağlık çalışanlarının çocuk ihmali ve istismarını tanıma düzeyleri. Çocuk ve Medeniyet Dergisi, 1(1), 101121.

Özbey, H., Gül, U., Özçelep, G. A. and Kahriman İ. (2018). Knowledge and awareness of nursing students about child abuse and. J Nurs Res Pract, 2(3), 21-25.

Özçevik, D., Güneş, Ö. D and Ocakçı, A. F. (2018). Hemşirelik öğrencilerinin sosyo-kültürel ve demografik özelliklerinin çocuk istismarı ve ihmali farkındalığı ile ilişkisi . ASHD, 17(2), 16-27.

Polat, O. and Reva, Z. (2019). Çocuk Hakları Sözleşmesi. O. Polat (Ed.) içinde, Tüm boyutlarıla çocuk istismart-2 önleme ve rehabilitasyon. Ankara: Seçkin Akademik ve Mesleki Yayınları. p.321-336

Poreddi, V., Pashapu, D. R., BV, K., Gandhi, S., El-Arousy, W. and Math, S. B. (2016). Nursing students' knowledge of child abuse and neglect in India. British Journal of Nursing, 25(5), 264-268. http://dx.doi.org/10.12968/bjon.2016.25.5.264

Read, J., Harper, D., Tucker, I. and Kennedy, A. (2018). Do adult mental health services identify child abuse and neglect? A systematic review. Int J Ment Health Nurs, 27, 7-19. https://doi.org/10.1111/inm.12369.

Sampson, M. and Read, J. (2017). Are mental health services getting better at asking about abuse and neglect. International Journal of Mental Health Nursing, 26, 95-104.

Uncu F. and Oğuzöncül F. (2013). Health care workers who work in the province of Elazig levels of awareness about child abuse and neglect, and the factors affecting this situation. International Journal of Medical Investigation, 1(1), 129-142

Uysal, A. (1998). Çocuk istismarı ve ihmalinin belirti ve risklerini tanılamada hemşire ve ebelerin bilgi düzeylerinin saptanması. Yüksek Lisans Tezi. Ege Üniversitesi, Sağlık Bilimleri Enstitüsü, İzmir

Victor-Chmil, J. and Foote, E. (2016). An Interprofessional Simulation for Child Abuse Reporting, Clinical Simulation in Nursing, 12(3), 69-73.

World Health Organization. Child Abuse. (2016). (cited 2020 May 4). Available from: ttps://www.who.int/en/news-room/fact-sheets/detail/childmaltreatment. 


\section{Citation Information}

Tek, S. and Karakaş, G.(2021). Awareness levels of child neglect and abuse in nursing students. OPUS-International Journal of Society Studies, 18(43), 6162-6176.DOI: 10.26466/opus.885123. 